\title{
Factors Affecting the Aggressive Behavior Among Vocational Students in Malaysia
}

\author{
Mohd Bekri Rahim, Sri Sumarwati, Faizal Amin Nur Yunus, Nizamuddin Razali, Khairul Anuar \\ Abdul Rahman
}

\begin{abstract}
The purpose of this research is to explore the most common factors affecting aggressive behavior among vocational students in Malaysia. The samples were composed of 400 vocational college students based on the proportional stratified random sampling method. The research design used is the quantitative method of survey. The modified Buss-Perry Aggression Questionnaire was used to identify the level of aggressive behavior among vocational students. A pilot study was conducted to 35 vocational college students in Batu Pahat. Based on the findings of the pilot study, the Cronbach's Alpha value item overall was 0.853 . This indicates that the questionnaire items were valid and reliable to obtain data on the actual survey. A total of 400 students from vocational colleges were selected for this study by the proportional stratified random sampling. The data were analyzed using the Statistical Package for Social Science (SPSS) program version 25 . Statistical techniques employed in the analysis of data collection were mean and standard deviation. The results showed that the majority of aggressive behavior of vocational students in Malaysia was at a moderate level. The findings of this study found that bad attitude, parents and electronic media were the factors of a moderate level aggressive behavior. Meanwhile, peer factor was at a high level in affecting aggressive behavior among vocational students in Malaysia. Furthermore, the study is expected to provide valuable information to teachers at vocational colleges to address social problems among the students for developing their character and moral toward excellence.
\end{abstract}

Keywords: aggressive behavior, counselling teachers, vocational college, moral.

\section{INTRODUCTION}

$\mathrm{T}_{\mathrm{h}}$ workers to realize the idea of Vision 2020 for the successful transformation of vocational education by targeting 1.3 million skilled workers [1]. Therefore, the Technical and Vocational Education Division plays an important role in line with the National Education Philosophy to ensure that vocational students are ready intellectually, spiritually,

Revised Manuscript Received on February 20, 2020.

* Correspondence Author

Sri Sumarwati*, University Tun Hussein Onn Malaysia, Parit Raja 86400, Batu Pahat, Johor, Malaysia. Email: sri_fatoni78@yahoo.com

Mohd Bekri Rahim, University Tun Hussein Onn Malaysia, Parit Raja 86400, Batu Pahat, Johor, Malaysia.

Faizal Amin Nur Yunus, University Tun Hussein Onn Malaysia, Parit Raja 86400, Batu Pahat, Johor, Malaysia.

Nizamuddin Razali, University Tun Hussein Onn Malaysia, Parit Raja 86400, Batu Pahat, Johor, Malaysia.

Khairul Anuar Abdul Rahman, University Tun Hussein Onn Malaysia, Parit Raja 86400, Batu Pahat, Johor, Malaysia.

(C) The Authors. Published by Blue Eyes Intelligence Engineering and Sciences Publication (BEIESP). This is an open access article under the CC BY-NC-ND license (http://creativecommons.org/licenses/by-nc-nd/4.0/) emotionally and physically [2]-[3]. Quality human resources is a valuable asset to a country, especially to solve many existing problems and advance the quality of society in general [4]-[5]. However, social problems are an issue that cannot be avoided from happening among students today. This is even more serious and will continue to spread if not checked early as well as underestimated by all parties [6]. Generally, social problems include various negative behaviors that do not carry the support and benefits to society. Negative treatment will continue to increase if no action is taken. One kind of adolescent behavior experiencing social problems is aggressive behavior [7]. Aggressive behavior can occur among children and adolescents where they physically attack such as pushing, hitting, attacking, mocking and killing. Aggressive behavior cannot be tolerated without taking any action. Aggressive behavior can lead to harming oneself and others. Discipline problems among students are at a critical phase because certain bad influences could not be filtered by the younger generation if they are not knowledgeable and unreliable [8]. Disciplinary problems that often occur among students are hanging out, gangsterism, bullying and drug abuse. Aggressive behaviors of criminal cases involving students include bullying and gangsterism in schools [9]. The teacher concern about the current social problem among students is unfounded. Social problems in Malaysia will get worse if not prevented. Based on the study conducted by [10], it was found that there was a significant increase in the number of students aged 13-18 who are involved in drug addiction. Besides, most of the youths at this age were first trying not only drugs, but also alcohol, tobacco, marijuana and other forbidden substances. Adolescents are the nation's human resource assets and have an important role in shaping the future political, economic and social conditions in our country. Teacher concerns over aggressive behavior that happens among students are very basic. Social problems in Malaysia seem to be getting worse if nobody is looking for the causes and solutions. One of the causes of social problems among students is the administration's attitude who is only concerned with academic achievement [11]. Such an attitude should be corrected to produce excellent students with good manners. Problems of aggressive behavior of vocational students are getting to the point of worrying when there were 23 students at the Vocational College pleading guilty in the Magistrate's Court in Kuala Terengganu on charges of injuring 3 students aged 16 and 17 years on 7 and 8 August 2017 outside a mosque [12]. Two days later, in the same college, 11 students were arrested by the police because of bullying and beating of a student [13].

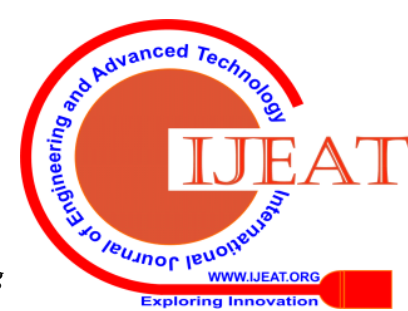




\section{Factors Affecting the Aggressive Behavior Among Vocational Students in Malaysia}

On February 11, 2018, a total of 4 Vocational College students in Sibu was arrested by the police for bullying. Therefore, a study should be conducted to explore the most common factor that can affect aggressive behavior among vocational students in Malaysia.

This study addresses the following research objectives:

i. Analyze the level of aggressive behavior among vocational students in Malaysia.

ii. Identify the bad attitude factor that can affect aggressive behavior among vocational students in Malaysia.

iii. Identify the parent factor that can affect aggressive behavior among vocational students in Malaysia.

iv. Identify the peer factor that can affect aggressive behavior among vocational students in Malaysia.

v. Identify the electronic media factor that can affect aggressive behavior among vocational students in Malaysia.

\section{AGGRESSIVE BEHAVIOR}

Aggressive behavior arises when an individual attacks other individuals [14]. The attack can occur orally or verbally with hostile intent with the behavior or actions that intend to injure other people. Aggressive behavior is a deliberate action made by individuals to achieve the desire to defend themselves or make other people helpless [15]. Therefore, it tends to be a negative behavior. There are some aggressive behaviors shown by adolescents. Two features are described in the study by [16], namely: Aggressive behavior among adolescents that is still at a level that can be controlled and not necessarily considered problematic. Behaviors like this happen because of feeling angry and disappointed due to a psychological condition that is temporary, thus actions by adolescents in these situations are understandable.

Uncontrolled aggression occurs when the nature of aggressive tendencies appear in adolescents which indicates an aggressive nature. This situation will have a negative impact on the person and the environment. The social problem needs to be detected at an early stage to take precautionary measures. Aggressive behavior is divided into three sections: physically aggressive behavior which is aimed to hurt someone, verbally aggressive behavior that is intended to hurt someone like taunts or threats like cursing and threatening someone to commit violence, and passive-aggressive behavior which aims to not hurt someone physically and verbally, for example, refusing to speak, silence, and not caring [17].

Any act such as smudging, smearing or damaging public property is considered as vandalism [18]. Based on previous studies conducted by [19], the students involved in vandalism seem to have lost the consideration of self and sanity to think. [15] also explained the reasons for aggressive behavior in more detail, namely:

i. Victims of violence. One of the causes of students who are aggressive is being a victim of aggressive behavior. The actions of those around the students who commit acts of violence are used as artificial objects. Students who have been victims will make other students as victims.

ii. Too spoiled. Desire can cause students to be aggressive; verbally and physically. This is because the students felt as having power and do not want to share it with others.

iii. Television and games. Adolescents often want to imitate aggressive and violent behavior by imitating the actions they see. In fact, the game that can affect their aggression acts as examples to perform the same action as they see it.

iv. Anger. Aggressive behavior can occur due to the emergence of unconscious anger in the students themselves. For example, a family environment that is not conducive and depressed such as elderly people fights, illnesses suffered by their parents, or traumatic situations generating dissatisfaction and disappointment.

\section{METHODOLOGY}

The research design is a survey with the quantitative method. The modified Buss-Perry Aggression Questionnaire [20] was used to identify the level of aggressive behavior among vocational students in Malaysia. The questionnaire which has 27 items was used to identify the factors affecting aggressive behavior among vocational students in Malaysia. The researcher used a 5 point Likert scale for alternative answers of respondents in the questionnaire. In the process of building items for research instruments, the researchers used content validity. The pilot study is the method used to assess the reliability of the questions contained in the questionnaire before the actual survey was conducted [21]. A pilot study was conducted to 35 vocational college students in Batu Pahat. If the Cronbach's alpha test results gained 0.6 and above, this indicates that the instrument is reliable and can be used [22]. Based on the findings of the pilot study, the Cronbach's alpha overall value of the item was 0.853 . This indicates that the questionnaire items were valid and reliable to obtain data on the actual survey. The study was conducted at 20 vocational colleges in Malaysia which are based on the North, South, Central and East zones. A total of 400 students from vocational colleges were selected for this study by proportional stratified random sampling. The data were analyzed using the Statistical Package for Social Science (SPSS) program version 25. Statistical techniques employed in the analysis of data collection were a mean and standard deviation.

\section{RESULTS AND DISCUSSIONS}

The number of male students involved in this study was $309(77.3 \%)$ and the number of female students involved in answering this questionnaire was 91 (22.8\%). Besides, the number of respondents involved in the Malaysian Vocational Certificate program was 275 (68.8\%) compared to the number of students of the Malaysian Vocational Diploma program at 125 (31.3\%).

A. Analysis of the level of aggressive behavior among vocational students in Malaysia was carried out.

Published By:

Blue Eyes Intelligence Engineering 
Table-I: The level of aggressive behavior among vocational students

\begin{tabular}{|c|l|c|c|}
\hline No & Categories & Frequency & Per cent \\
\hline 1 & High & 149 & 37.25 \\
\hline 2 & Moderate & 153 & 38.25 \\
\hline 3 & Low & 98 & 24.5 \\
\hline
\end{tabular}

The study found that $37.25 \%$ aggressive behavior of respondent was at a high level, $38.25 \%$ at a moderate level and $24.50 \%$ aggressive behavior at a low level.

Thus, the majority of the aggressive behavior level of vocational students in Malaysia was at moderate. The findings of this study are in line with the study by [23] who conducted a study on youth in Pakistan, where the results of their survey found that the majority of aggressive behavior in adolescents were at a moderate level. The study is parallel to the current study due to the similarity in the age range of respondents, namely 17-26 years. Physical and sociological development of adolescents started at age 17 years and over where the teenager practices his/her role as an adult [24]. The change from adolescence to adulthood is a time that confuses adolescents because these youths are going through a critical phase of change, both mentally and physically. Therefore, they tend to do as they please so this group is easily influenced by negative behavior due to a high level of curiosity that makes them perform an action or activity without thinking well in advance. They are very likely to follow the desires of self or peers.

\section{B. Units}

Table-II: The bad attitude factor can affecting aggressive behavior among vocational students

\begin{tabular}{|l|l|l|l|l|}
\hline No & Item & Mean & $\begin{array}{l}\text { Standard } \\
\text { Deviation }\end{array}$ & Level \\
\hline 1 & $\begin{array}{l}\text { I've been damaging school } \\
\text { equipment }\end{array}$ & 3.70 & 0.648 & High \\
\hline 2 & $\begin{array}{l}\text { I've been doing belongings } \\
\text { friends in college without } \\
\text { permission }\end{array}$ & 3.25 & 0.573 & Moderate \\
\hline 3 & $\begin{array}{l}\text { When I am angry, I will ruin } \\
\text { an object }\end{array}$ & 2.48 & 0.813 & Moderate \\
\hline 4 & $\begin{array}{l}\text { I've been do not return the } \\
\text { items I borrowed }\end{array}$ & 3.53 & 0.762 & Moderate \\
\hline 5 & $\begin{array}{l}\text { I've been taking my parent's } \\
\text { money without them } \\
\text { knowing }\end{array}$ & 3.15 & 0.478 & Moderate \\
\hline 6 & $\begin{array}{l}\text { I've been calling people by } \\
\text { nicknames embarrassing }\end{array}$ & 3.62 & 0.712 & Moderate \\
\hline 7 & I've been threatening others & 3.14 & 0.455 & Moderate \\
\hline 8 & I've been hurting friends & 2.42 & 0.778 & Moderate \\
\hline 9 & $\begin{array}{l}\text { I've been damaging public } \\
\text { property }\end{array}$ & 3.76 & 0.677 & High \\
\hline The sum of the mean & & $\begin{array}{l}\text { Moderate } \\
\text { (3.23) }\end{array}$ \\
\hline
\end{tabular}

Based on previous studies conducted by [25], the factor of trying new things has a high Per centage among students. The findings of this study found that the bad attitude factor is at a moderate level in affecting aggressive behavior among vocational students. The results showed the highest mean value of 3.76 with a standard deviation of 0.677 and the lowest mean value of 2.42 with a standard deviation of 0.778 , but the overall mean score was moderate at 3.23. Students generally do not realize that smoking can kill in so many ways [26]. This finding was also supported by [27] which stated that in their adolescent age, they want freedom in all sorts of things. Furthermore, they suffer from rapid physical and mental development.

C. Identifying the parent factor affecting aggressive behavior among vocational students in Malaysia.

Table-III: The parent factor can affecting aggressive behavior among vocational students

\begin{tabular}{|c|c|c|c|c|}
\hline No & Item & Mean & \begin{tabular}{|c|} 
Standard \\
Deviation \\
\end{tabular} & Level \\
\hline 1 & $\begin{array}{l}\text { When my parents were angry, they are } \\
\text { often raging }\end{array}$ & 3.80 & 0.613 & High \\
\hline 2 & $\begin{array}{l}\text { My parents do not care about my } \\
\text { lessons }\end{array}$ & 3.44 & 0.729 & Moderate \\
\hline 3 & $\begin{array}{l}\text { My parents always biased of my } \\
\text { siblings }\end{array}$ & 3.53 & 0.762 & Moderate \\
\hline 4 & $\begin{array}{l}\text { My parents rarely stay at home because } \\
\text { they are busy with work }\end{array}$ & 3.59 & 0.738 & Moderate \\
\hline 5 & Sometimes, my parents never prayed & 3.17 & 0.498 & Moderate \\
\hline 6 & $\begin{array}{l}\text { My parents less communicate with me } \\
\text { about the problem I've been facing }\end{array}$ & 3.71 & 0.854 & High \\
\hline 7 & Sometimes, my parents are fighting & 3.17 & 0.498 & Moderate \\
\hline 8 & $\begin{array}{l}\text { my parents don't care about the things I } \\
\text { do }\end{array}$ & 3.82 & 0.831 & High \\
\hline \multicolumn{4}{|c|}{ The sum of the mean } & $\begin{array}{l}\text { Moderate } \\
\text { (3.53) }\end{array}$ \\
\hline
\end{tabular}

The study by [28] showed that ineffective communication will have a negative impact on the family and the behavior of children. The findings of this study showed that the parent factor is at a moderate level in affecting aggressive behavior among vocational students. The results showed that the highest mean value was 3.82 with a standard deviation of 0.831 and the lowest mean value was 3.17 with a standard deviation of 0.498 , but the overall mean score was moderate at 3.53. These findings support the study by [29] which found that support from the parent can have a positive behavior among children, while the parents who like punishing can lead to negative behavior among children. The role of parents is crucial to control the activities of their children rather than being involved in social problems [30]. The first responsibility that exists in human life comes from family. This is because education and care in the family was the first institution in the process of development and education of children and adolescents. Thus, the failure of parents to teach children can affect their future if their child is involved in social problems and does not have the motivation to succeed.

D. Identifying the peer factor affecting aggressive behavior among vocational students in Malaysia.

Table-IV: The peer factor can affecting aggressive behavior

\begin{tabular}{|c|l|c|c|c|}
\hline No & \multicolumn{1}{|c|}{ Item } & Mean & $\begin{array}{c}\text { Standard } \\
\text { Deviation }\end{array}$ & Level \\
\hline 1 & My friend often invite me to smoke & 3.74 & 0.836 & High \\
\hline 2 & $\begin{array}{l}\text { My friend often invite me to waste } \\
\text { time like "hanging out" }\end{array}$ & 3.95 & 0.623 & High \\
\hline 3 & $\begin{array}{l}\text { I often refer to my peers to make a } \\
\text { decision }\end{array}$ & 4.10 & 0.638 & High \\
\hline 4 & $\begin{array}{l}\text { My peers have influenced my } \\
\text { thinking }\end{array}$ & 3.66 & 0.752 & Moderate \\
\hline 5 & $\begin{array}{l}\text { I often talk about my problems to my } \\
\text { peers }\end{array}$ & 3.84 & 0.829 & High \\
\hline 6 & $\begin{array}{l}\text { I more trust my peers compared to } \\
\text { my family }\end{array}$ & 3.90 & 0.548 & High \\
\hline \multicolumn{2}{|l|}{ The sum of the mean } & $\begin{array}{l}\text { High } \\
\text { (3.87) }\end{array}$ \\
\hline
\end{tabular}


Based on Table 4, the findings showed that the peer factor is at a high level in affecting aggressive behavior among vocational students. The results showed that the highest mean value was 4.10 with a standard deviation of 0.638 and the lowest mean value was 3.66 with a standard deviation of 0.752 , but the overall mean score was high at 3.87. This finding was confirmed by a study conducted by [31] who found that adolescents involved in social problems were influenced by peers. Besides, the results of this study support the findings by [32] who found that peer influence has a very important role in the formation of adolescent behavior. This is probably because of the decision taken by a student that usually tends to follow his friends and based on their views.

E. Identifying the electronic media factor affecting aggressive behavior among vocational students in Malaysia.

Table-V: The electronic media factor can affecting aggressive behavior among vocational students

\begin{tabular}{|c|l|c|c|c|}
\hline No & \multicolumn{1}{|c|}{ Item } & Mean & $\begin{array}{l}\text { Standard } \\
\text { Deviation }\end{array}$ & Level \\
\hline 1 & $\begin{array}{l}\text { I like to see the violent action scene } \\
\text { (aggressive) in electronic media. }\end{array}$ & 3.92 & 0.595 & High \\
\hline 2 & $\begin{array}{l}\text { Exploring pornographic websites makes } \\
\text { me excited. }\end{array}$ & 3.31 & 0.621 & Moderate \\
\hline 3 & $\begin{array}{l}\text { I like to imitate violent actions which are } \\
\text { aired on electronic media. }\end{array}$ & 3.66 & 0.683 & Moderate \\
\hline 4 & $\begin{array}{l}\text { I like to imitate an action actor who } \\
\text { holds an evil character. }\end{array}$ & 2.48 & 0.813 & Moderate \\
\hline 5 & $\begin{array}{l}\text { I feel great when I can imitate the evil } \\
\text { character of my idol artist. }\end{array}$ & 3.26 & 0.638 & Moderate \\
\hline \multicolumn{2}{|l|}{ The sum of the mean } & $\begin{array}{l}\text { Moderate } \\
\text { (3.33) }\end{array}$ \\
\hline
\end{tabular}

Mass media in the era of globalization such as television, radio and smartphones also have a negative impact [33]. Based on the data analysis in Table 4, these findings showed that electronic media is at a moderate level in affecting aggressive behavior among vocational students. The results showed that the highest mean value was 3.92 with a standard deviation of 0.595 and the lowest mean value was 2.48 with a standard deviation of 0.813 , but the overall mean score was moderate at 3.33. According to a study conducted by [34], web browsing is the most popular activity by students. Students spend more time gaining knowledge and information through electronic media, for example through Google, Facebook, YouTube and Instagram. Students are susceptible to violent acts because of the very weak screening of the videos. Moreover, the lack of parental supervision is also a factor. It can be concluded that the electronic media have an important role in influencing the minds and attitudes of adolescents who often see negative materials by surfing pornographic websites and websites that are inappropriate for adolescents.

\section{CONCLUSION}

The Malaysian government aims to produce graduates of technical and vocational education with knowledge, skills, and responsible. However, the social problem is a phenomenon that is difficult to prevent from occurring among students. Aggressive behavior will continue to increase if no action is taken. No matter what the main cause of social problems is, proactive preventive measures need to be taken to eliminate social problems from continuing to spread among students. This study aims to explore the most common factors affecting aggressive behavior among vocational students in Malaysia. The factors that cause social problems among vocational students which are a namely bad attitude, parents, peer and electronic media have been described through descriptive analysis of the highest overall mean of the four factors studied. The results showed that the majority of the aggressive behavior of vocational students in Malaysia was at a moderate level. The findings of this study found that bad attitude, parent and electronic media factors were at a moderate level in affecting aggressive behavior among vocational students. Meanwhile, the peer factor is at a high level in affecting aggressive behavior among vocational students in Malaysia. Passion, attitude and wanting to try to have the fun as teenagers also contribute to bad behavior. They keep trying to find new experiences even if they have experienced failure and hardship. Based on the results of this study, more students feel that what they do is right and do not want to be restricted in everything they do. Besides, based on the analysis conducted, the factors that affect the students to be involved in social problems (aggressive behavior) is peers. Peer influence plays an important role in forming individual traits and emotions. The study also showed that the respondents would rather spend time with their peers than their family. They often refer to their peers to make a decision. This is because most of the respondents live in a dorm. Thus, their friends are the only people they can express their thinking and do their joint activities. This research found that bad attitude, parent and electronic media factors have a moderate effect on the respondents. However, based on the analysis in this study, there are situations where parents are less concerned with certain aspects of educating their children. For example, parents often curse when angry. Although this aspect is at a moderate level, the researcher believes that students will have aggressive behavior because of their rebellious souls. Besides, the lack of communication between vocational students and their parents is also a factor.

Based on the responses of students, this study shows that students like to see the scenes of violent action (aggressive) in the electronic media. This has influenced the development of youth culture toward negative behavior. Therefore, all parties should work together to reduce this aggressive behavior. Furthermore, the study is expected to provide valuable information to teachers at vocational colleges to address social problems among vocational students for developing the character and moral of students toward excellence. Besides, the findings of this study can be a source of information for the Ministry of Education in making in-service training for teachers. In this way, teachers have the knowledge and skills to face the aggressive behavior among vocational student.

\section{ACKNOWLEDGMENT}

The authors would like to thank the Ministry of Education Malaysia for supporting this research under the Grant PPG VOT V029.

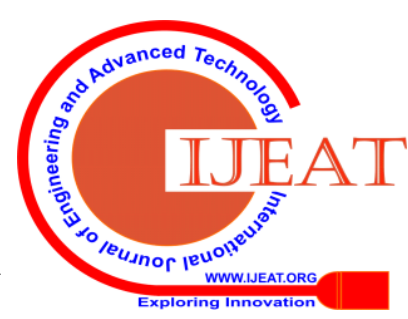




\section{REFERENCES}

1. Malaysian Education Ministry, 2012, Vocational College Rationale. Reached from: http: //www.stdlm.com/portal/attachments/article/53/a)\% 20RASIONAL\% 20KV.pdf

2. Malaysia Education Ministry, 2018, National Education Philosophy, Reached from: https: //www.moe.gov.my/index.php/my/dasar/falsafah-pelajarankebangsaa n.

3. Faizal, A.N.Y., Saiful, H.M., Bekri, Jamil, A.B., R., Amiruddin, M.H., Ruhizan, M.Y., Arasinah. K.Work Environment Impact on Learning Transfer of Malaysia Skill Training. Special Edition of Pertanika Journal of Social Sciences and Humanities: TVET Talent Development: Advancing Society Through Quality, Technology, Innovation and Skill Mobilisation. JSSH Vol. 25(S) May 2017. 33-40.

4. Sumarwati, S., Yunos, J. M. and Ibrahim, B., Transferable Skills for PhD Students to Complete the Journey, Advanced Science Letters, 2017, 23 (2), 968-971, DOI: https://doi.org/10.1166/asl.2017.7459.

5. Ismail, A., Kasman, Z., Sumarwati, S., Yunus, F. A. N., Samad, N. A. The development of job competency for skilled technical worker towards green technology. International Journal of GEOMATE, 2019, 17 (59): 216-221. DOI: https://doi.org/10.21660/2019.59.

6. Noor, A. F. M., Jasmi, K. A., and Shukor, K. A., Social Problems Among Students and The Role Of Lecturers Of Islamic Education in Teaching and Learning. Journal of Social Sciences and Humanities, 2017, 11 (2), 050-061.

7. Yahaya, A., Yow, K. G., \& Abdul, A. H. Effectiveness of the Ethics Program at the Henry Gurney School of Hygiene. Values in Post-Modern Communities, 2003, pp. 119-125.

8. Ghani, M. F. A., Ayub, A., Abdullah, Z., Elham, F., Khanayatullah, H. B., and Radzi, N. M., Disciplinary Problems of Islamic Students: Strategies and Solutions to Islamic Education Curriculum. Jurnal Hadhari, 2017, 9 (1), pp. 91-110.

9. Shafie, A. A. Anuar, A. A., Rozudi, N. C., Kamaruddin, W. A. Z. W. and Mohamad, M. B., Bully Victims and the Effects of Bullying, Journal of Islamic Social Sciences and Humanities, 2017, 11, pp. 109-124.

10. Ismail, R., Ahmad, N. A., Ibrahim, F. and Nen, S., The Influence of Individual, Familial and Social Environmental Factors Towards Substance Abuse Behavior among Adolescents. Akademika, 2017, 87 (1): pp. 7-16.

11. Sulaiman, H., Tanjung, A. S., Khalid, N. M., Razak, N. A., \& Salleh, N. H. (2013). Emotional Intelligence in Improving Adolescent Personality. Asia Pacific Curriculum \& Teaching Journal, pp. 28 - 33.

12. Berita Harian. (12 Februari, 2018). BH Online. Retrieved from bharian.com.my: 2018/02/387861/ kadar-jenayah-pelajar-masih-rendah-kpn/amp

13. Utusan. (17 Februari, 2018). Retrieved from m.utusan.com.my: m.utusan.com.my/berita/luar-negara/remaja-didakwa-17-tuduhan-bun uh-1.610964

14. Pristiwalyyo, T \& Sodiq, M. Child Education Emotional Disorders. Deputy CEO. Proceedings of the 5th Islamic Discourse on Discourse; 2005, 1-8. UKM. Bangi: Fakulti

15. Myers, D. G. Social psychology South Jakarta: Salemba Humanika 2012. Universiti Teknologi Malaysia Malaysia, Skudai, Johor.

16. Izzaty, R. E. Student Participant Development. Yogyakarta: UNY Press, 2005.

17. Berkowitz, L. Aggresion: Itscauses, consequences, and control. 2005, New York:Mc Graw-Hill.

18. Ahmad, J., Ismail, N. and Nasir, N. N. A. M., 2017, Youth and Current Crime Issues in Malaysia. Malaysian Journal of Youth Studies, 16, pp. 49-70.

19. Gan, S. E. (2013). Vandalisme among National High School Students in the Labis Zone, Johor. Universiti Technology Malaysia: Undergraduate Project.

20. Buss, A. H. and Perry, M., The Aggression Questionnaire, Journal of Personality \& Social Psychology, 1992, 63 (3), pp. 452-259.

21. Chua Y. P., 2006, Research Methods 1. (Malaysia: Mc Graw-Hill).

22. Najib, M. A. G., 2003, Design of Educational Survey Review, (Johor: Universiti Teknologi Malaysia).

23. Imtiaz, R., Yasin, G. \& Yaseen, A. Sociological Study of the Factors Affecting the Aggressive Behavior among Youth. Pakistan Journal of Social Sciences (PJSS), 2010, 30 (1), pp. 99-108.

24. Rashid, A. R. A. Addressing the Development and Problems of Adolescent Behavior in the Family. Universiti Malaya: Pusat Pembangunan Keluarga, 2006. https://www.google.com/amp/s/www.bharian.com.my/berita/nasional/

25. Sharif, Z., and Roslan, M., Factors Influencing Teens Involved In Social Issues Tunas Bakti School, Lereh River, Melaka, Journal of Education Psychology \& Counseling, 2011, 11 (1), pp. 115-140.

26. Lubis, M. A., Spiritual Practice in Developing Student Discipline, Bangi: Universiti Kebangsaan Malaysia, 2014.

27. Sarnon, N., Saim, N. H., Ibrahim, F., Zakaria, E., Nen, S. and Hoesni. S. M., 2018, Exploring the Role of Youth Uncontrollable on Family Issues: Towards Understanding the Adolescent Self Discovery Family Dysfunction, Rizal, S., Ishak, H. and Amran, N. N., Relationship between Habits Parent with Adolescence Behavior, Proceedings of International Conference on Islam, Development and Social Harmony in Southeast Asia, 2017.

28. Ismail, A. B., Salleh, S. M. and Jemali, M., 2016, The Analysis of Parents Coaching Forms for Developing an Excellent Personality: Study on Sekolah Menengah Kebangsaan Pulau Sebang, Alor Gajah, Melaka. Jurnal Perspektif, 8 (2), pp. 1-10

29. Suastini, N. W. The relationship between authoritarian parenting and adolescent aggressive behavior. Journal of Research, 2011, 1(1), pp 97-108.

30. Kreager, D. A., Staff, J., Gauthier, R., Lefkowitz, E. S. and Feinberg, M. E., The Double Standard at Sexual Debut: Gender, Sexual Behavior and Adolescent Peer Acceptance, Sex roles, 2016, 75 (7), pp. 377-392. doi:10.1007/s11199-016-0618-x

31. Shahruddin, N. J., Mansor, M., Zainal Madon, Z. and Hamsan, H. H., Relationship between Peer Influences, Self Esteem and Locus of Control with Attitude Towards Sexual Behavior, Akademika, 2018, 88 (2), pp. 81-94. https://doi.org/10.17576/akad-2018-8802-06

32. Hamid, S. A., Mass Media Effect on Changes in Social Community, 2016, Special Issue 1, pp. 214-226.

33. Hamat, W., The Influence of Mass Media on the Moral Performance of Malaysian Polytechnic Islamic Students, The Online Journal of Islamic Education, 2013, 1 (1), pp. 17-27.

\section{AUTHORS PROFILE}

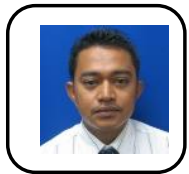

Mohd Bekri Rahim is a senior lecturer in the Department of Engineering Education at the Faculty of Technical \& Vocational, Universiti Tun Hussein Onn Malaysia. He holds PhD from Universiti Kebangsaan Malaysia in technical and vocational education, in 2015, master's degree in Technical Education (Mechanical Engineering) from Universiti Tun Hussein Onn Malaysia and bachelor's degree from Universiti Kuala Lumpur. His research interest includes technical and vocational education training (TVET), psychology education and engineering education.

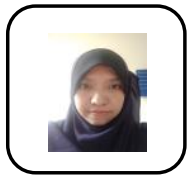

Sri Sumarwati is a $\mathrm{PhD}$ student in Technical and Vocational Education, at the Faculty of Technical and Vocational Education from University Tun Hussein Onn Malaysia. She previously received her master degree from University Tun Hussein Onn Malaysia in technical and vocational education, in 2014 and a bachelor's degree in mathematics education from Universitas Ahmad Dahlan Indonesia. He research interest includes engineering education, psychology education, transferable skills, mathematics education and entrepreneurship program.

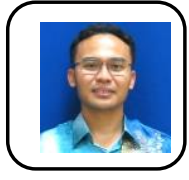

Faizal Amin Nur Yunus is a senior lecturer in the Department of Engineering Education at the Faculty of Technical \& Vocational, Universiti Tun Hussein Onn Malaysia. He holds a PhD from Universiti Kebangsaan Malaysia in technical and vocational education, in 2015, bachelor's degree and master's degree in Technical Education (Mechanical Engineering) from Universiti Tun Hussein Onn Malaysia. His research interest includes Skill and training, Technical and Vocational Educational Training, Employability and Vocational Pedagogy.

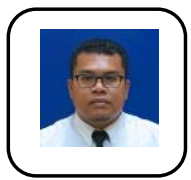

Khairul Anuar Abdul Rahman is a senior lecturer in the Department of Engineering Education at the Faculty of Technical \& Vocational, Universiti Tun Hussein Onn Malaysia. He holds a PhD from Universiti Teknolog Malaysia in technical and vocational education, in 2016 , and a bachelor's degree in Engineering Education from Universiti Teknologi Malaysia. His research interest includes Alternative of teaching and learning in TVET, Competency Base Education and Project Oriented Problem Based Learning. .

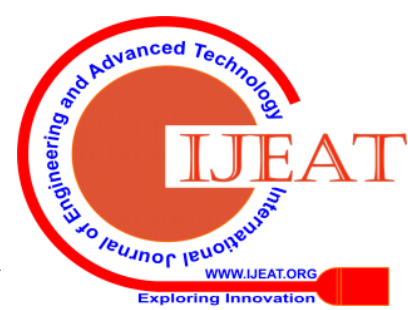




\section{Factors Affecting the Aggressive Behavior Among Vocational Students in Malaysia}

Nizamuddin Razali is a senior lecturer in the Department of Engineering Education at the Faculty of Technical \& Vocational, Universiti Tun Hussein Onn Malaysia. He holds a PhD from Universiti Sains Malaysia in technology education and multimedia, in 2017, master's degree from Universiti Malaya and bachelor's degree from Universiti Teknologi Malaysia. His research interest includes Technical \& Vocational Education and Training (TVET), Competency-based training (CBT), Technical competency and Engineering education. 